\title{
A Measurement of the Frontal Sinus Ostium Using the Sagittal Images of Computed Tomography
}

\author{
Sang Woo Yoo, Young Chang Sim, Ha Min Jeong, and Jae Hoon Lee \\ Department of Otolaryngology-Head \& Neck Surgery, Institute of Wonkwang Medical Science, School of Medicine, \\ Wonkwang University, Iksan, Korea
}

\section{시상면 부비동 전산화단층촬영을 이용한 전두동 자연공의 계측}

유상우 · 심영창 · 정하민 · 이재훈

원광대학교 의과대학 이비인후과학교실

Received May 26, 2014

Revised July 15, 2014

Accepted July 16, 2014

Address for correspondence

Jae Hoon Lee, MD, PhD

Department of Otolaryngology-

Head \& Neck Surgery, Institute of

Wonkwang Medical Science,

School of Medicine,

Wonkwang University,

895 Muwang-ro,

Iksan 570-711, Korea

Tel $+82-63-859-1441$

Fax $+82-63-841-6556$

E-mail leejaehoon64@gmail.com
Background and Objectives Endoscopic management of frontal sinus disease remains a difficult task. In order to minimize the risk of intracranial complication, easily identifiable landmarks and measurements should be required. This study aims to identify standard distances from the columella to the anterior and posterior borders of the frontal sinus ostium in Korean men and women.

Subjects and Method We obtained the sagittal images taken from 30 men and 30 women. Measurements from the columella to the nasofrontal beak (NFB) and anterior skull base (ASB) were made. Also, the angle between the lines of the columella to the ASB and hard palate was measured.

Results The mean distance from the columella to the NFB was $55.3 \pm 3.9 \mathrm{~mm}$ in men and $52.1 \pm$ $4.7 \mathrm{~mm}$ in women $(p<0.01)$. The mean distance from the columella to the ASB was $62.1 \pm 4.5$ $\mathrm{mm}$ in men and $59.0 \pm 4.7 \mathrm{~mm}$ in women $(p<0.01)$. The mean angle between the lines of the columella to the ASB and hard palate was $71.8 \pm 4.5^{\circ}$ in men and $70.7 \pm 4.6^{\circ}$ in women $(p>0.05)$.

Conclusion This study suggests sinus surgeons to stay a distance from the columella of less than $57.6 \mathrm{~mm}$ in men and $54.3 \mathrm{~mm}$ in women to minimize skull base injury.

Korean J Otorhinolaryngol-Head Neck Surg 2014;57(11):766-8

Key Words Endoscopy $\cdot$ Frontal sinus $\cdot$ Measurement $\cdot$ Radiology $\cdot$ Surgery.

\section{서 론}

비강 및 부비동은 해부학적으로 두개저에 인접하고 그 주위 에는 중요한 혈관과 신경들이 존재한다. 특히 전두동은 공간 이 협소하고 주위에 전사골동맥, 안와, 두개기저부, 지판 및 활 차상신경, 안와상신경 등 중요한 구조물이 있어 전두동 천공 술 및 부비동 내시경 수술시 심각한 합병증을 유발할 수 있다. 그래서 전두동 및 전두동 개구부에 대한 포괄적인 이해가 부 비동 내시경 수술에 있어 합병증 예방 및 성공적인 치료 효과 를 위해 필수적이다. ${ }^{1)}$

현재는 만성 부비동염의 수술적 치료로 부비동 내시경 수술
이 많이 시행되고 있지만 전두동은 전상방에 위치하고 있으며 전두동와가 좁아 수술시야가 좁고, 수술 후 협착이 잘 생겨 비 강을 통해 접근하기 가장 어려운 부비동이다. 과거부터 단순 방 사선학적 연구로 시작하여 전산화단층촬영을 이용한 계측, 시 체 해부를 통한 계측들이 이루어져 왔다. ${ }^{2-6)}$

최근 항법장치의 보급은 부비동 내시경 수술에서 술자에게 술 전 확인한 병변과 주위 중요한 구조물과의 방사선학적인 관 계를 수술시야에서 정확히 확인하여 중요한 구조물의 손상을 피하는 데 도움을 준다. 그러나, 고가의 장비 구입 및 의료비용 의 상승을 야기하며 환자의 수술 중 발생하는 움직임을 방지 하기 위해 전신마취가 필요하며 모든 부비동 내시경 수술에 사 
용하기에는 제한점이 있다. ${ }^{7)}$

국내에서는 부비동 전산화단층촬영을 이용한 전두동 자연 공을 중심으로 하는 방사선학적 계측에 대한 연구는 아직까 지 없었다. 이에 저자들은 Eloy 등이이 제시하였던 지표들을 시 상면 영상을 이용하여 한국인 정상 성인 남녀를 대상으로 비 주(columella)로부터 비전두동 부리(nasofrontal beak)와 전 뇌기저부(anterior skull base)까지의 거리를 각각 계측한 후, 한국인에서 전두동 자연공을 중심으로 비강입구까지의 거리 를 얻고자 하였다.

\section{대상 및 방법}

\section{대 상}

2012년 1월부터 12월까지 본 병원에 내원하여 부비동 전산 화단층촬영을 했던 20세에서 70세까지 환자 중 남녀 각각 30 명씩 무작위 선택하여 연구를 수행하였다. 대상군의 평균나이 는 남자는 47.3 \pm 15.7 세, 여자는 $50.1 \pm 12.2$ 세였다. 연구대상군 은 부비동 전산화단층촬영에서 전두동 및 전두동 자연공이 관 찰되면서 전두동염이 미미하거나 전혀 없는 경우로 하였다. 전 두동 자연공에 대해 부비동 단층촬영을 통한 방사선 계측에 혼돈을 줄 수 있는 심한 다발성 코폴립, 전두동 개구부 봉소, 전두동염, 과거 코 수술 기왕력, 최근 혹은 과거 안면 골절, 종 양이 있는 경우와 전두동 발달이 거의 안된 경우 및 전혀 안된 경우는 제외하였다.

\section{고해상력 부비동 단층촬영을 통한 분석}

60명의 연구대상군에게 축상면 부비동 단층촬영을 시행하 였다. 단층촬영은 Somatom Definition Flash 256-slice CT scanners(Simens Healthcare, Forchheim, Germany)를 이용 하여 $1 \mathrm{~mm}$ 두께로 축상면을 측정하였으며, 관상면과 시상면 은 Wizard workstation(Simens Healthcare, Forchheim, Germany)을 통해 $2 \mathrm{~mm}$ 두께로 재구성되었다.

부비동 전산화단층촬영의 시상면 영상을 이용하여 방사선 학적으로 전두동 자연공을 계측하였다. 좌, 우측의 시상면 영 상 중에서 각측의 전두와(frontal sinus recess)의 정중선 영상 을 선택하여 비주의 가장 앞부위(A)로부터 비전두동 부리의 가장 돌출된 부위(B)까지의 거리(A-B선), 비주의 가장 앞부 위(A)로부터 비전두동 부리의 가장 돌출된 부위를 지나 전뇌 기저부(C)까지의 거리(A-C선)(Fig. 1), 비주에서 비전두동 부 리를 지나 전뇌기저부까지의 직선 $(\mathrm{A}-\mathrm{C}$ 선 $)$ 과 경구개에 평행하 는 수평면과의 각도(Fig. 2)를 계측하였다. 거리와 각도에 대해 좌, 우측을 각각 계측하여 평균값을 얻었다. 측정오류를 막기 위해 모든 계측치는 2 명의 관찰자에 의해 각자 2 회 반복 측정
한 수치를 평균한 값으로 하였다.

통 계

통계학적 분석은 SPSS version 12.0 program(SPSS Inc., Chicago, IL, USA)을 이용하여 시상면에서 계측된 각각의 수 치는 평균표준편차로 나타내고, 평균비교는 Student's t 검정 을 사용하였다. 유의성은 $p$ 값이 0.05 미만인 경우에 통계적으 로 유의하다고 판정하였다.

\section{결 과}

비주로부터 비전두동 부리까지의 거리(Table 1)

좌측 및 우측을 포함한 양측의 평균거리는 남자는 $55.3 \pm$ $3.9 \mathrm{~mm}$, 여자는 $52.1 \pm 4.7 \mathrm{~mm}$ 로 남녀 간 유의한 차이를 보였 다 $(p<0.01)$. 연구대상군 각각 개인에서의 좌, 우측 코에서 비

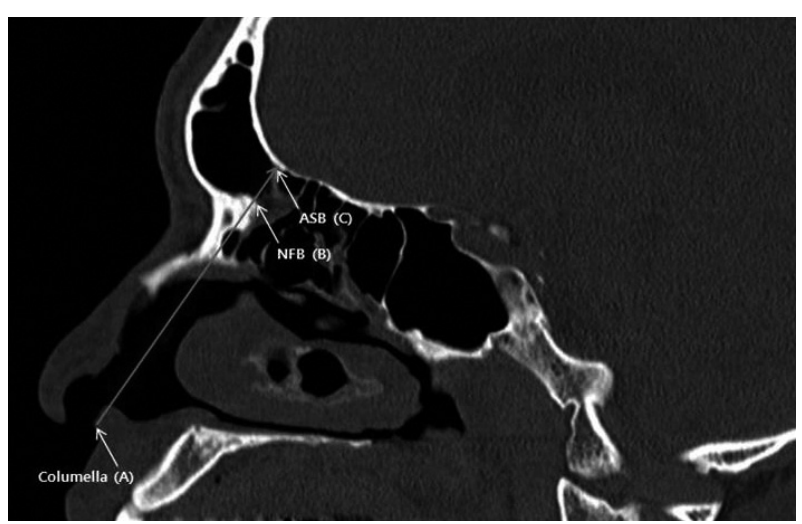

Fig. 1. Sagittal computed tomography image of the paranasal sinuses. The image shows the distances from the columella to the nasofrontal beak (NFB) and anterior skull base (ASB). Columella (A), NFB (B), ASB (C).

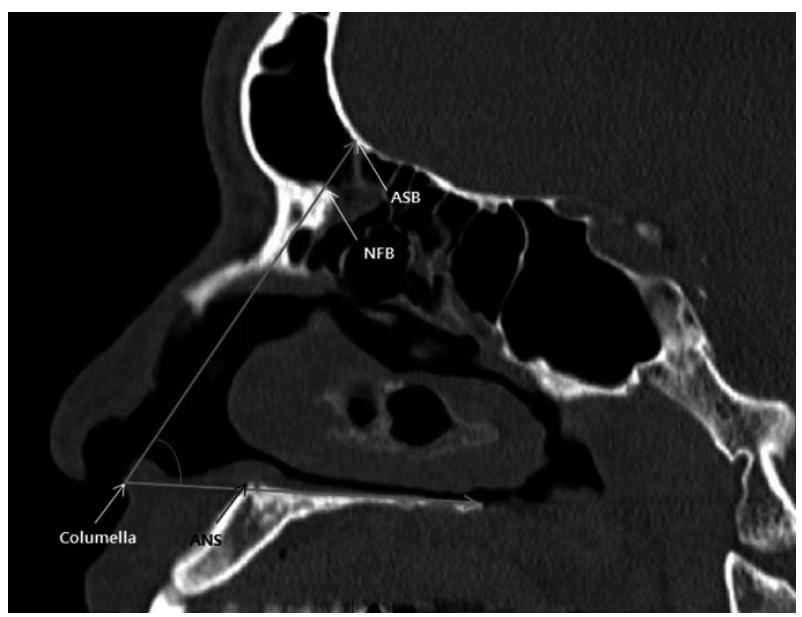

Fig. 2. Sagittal computed tomography image of the paranasal sinuses. The image shows the angle between the lines of the columella to the anterior skull base (ASB) and hard palate. NFB: nasofrontal beak, ANS: anterior nasal spine. 
Table 1. The mean distances from the columella to the NFB and the ASB of Korean adult male and female patients

\begin{tabular}{|c|c|c|}
\hline & $\begin{array}{l}\text { Columella to NFB } \\
(\text { mean } \pm \text { SD })\end{array}$ & $\begin{array}{c}\text { Columella to ASB } \\
(\text { mean } \pm \text { SD })\end{array}$ \\
\hline \multicolumn{3}{|l|}{ Male (mm) } \\
\hline Left & $55.5 \pm 4.0$ & $62.6 \pm 4.4$ \\
\hline Right & $55.2 \pm 3.9$ & $61.6 \pm 4.6$ \\
\hline Overall & $55.3 \pm 3.9^{* *}$ & $62.1 \pm 4.5^{* *}$ \\
\hline \multicolumn{3}{|c|}{ Female $(\mathrm{mm})$} \\
\hline Left & $52.1 \pm 4.7$ & $59.0 \pm 4.9$ \\
\hline Right & $52.1 \pm 4.9$ & $59.1 \pm 4.5$ \\
\hline Overall & $52.1 \pm 4.7^{* *}$ & $59.0 \pm 4.7^{* *}$ \\
\hline
\end{tabular}

$* * p<0.01$. NFB: nasofrontal beak, ASB: anterior skull base, SD: standard deviation

주로부터 비전두동 부리까지의 거리는 유의한 차이를 보이지 않았다 $(p>0.05)$.

\section{비주로부터 전뇌기저부까지의 거리(Table 1)}

양측을 포함한 평균거리는 남자는 $62.1 \pm 4.5 \mathrm{~mm}$, 여자는 59.0 $\pm 4.7 \mathrm{~mm}$ 로 남녀 간 유의한 차이를 보였다 $(p<0.01)$. 연구대상 군 각각 개인에서의 좌, 우측 코에서 비주로부터 전뇌기저부까 지의 거리는 유의한 차이를 보이지 않았다 $(p>0.05)$.

\section{비주에서 비전두동 부리를 지나 전뇌기저부까지의 직선과 경구개에 평행하는 수평면과의 각도}

양측을 포함한 평균각도는 남자는 $71.8 \pm 4.5^{\circ}$, 여자는 70.7 $\pm 4.6^{\circ}$ 로 남녀 간 유의한 차이를 보이지 않았다 $(p>0.05)$. 연구 대상군 각각 개인에서의 좌, 우측 코에서 각도는 유의한 차이 를 보이지 않았다 $(p>0.05)$.

\section{고 찰}

최근 전산화단층촬영의 고해상도 영상과 더불어 축상면 영 상을 촬영한 후 관상면 영상과 시상면 영상을 3차원적으로 재 구성하는 기술이 개발됨에 따라, 과거 축면 및 관상면 영상만 으로는 측정이 어려웠던 비강 및 부비동의 주요 구조물 간의 거 리 및 변이를 파악하는 데 도움을 준다.5) 전두동 개구부는 해부 학적 변이가 심할 뿐 아니라 내측으로는 후각신경, 가측으로는 지판, 후방으로 사골포 및 전사골동맥으로 경계되어져 있다.

Moon 등 ${ }^{4}$ 은 한국인 사체 해부를 통해 비역(limen nasi) 및 비공 아랫점(nasal sill)으로부터 전사골동맥관까지의 평균 거 리 및 각도를 측정하였는데 비역으로부터 전사골동맥관까지 의 거리는 $49.0 \pm 4.3 \mathrm{~mm}$ 였으며 경구개에 평행하는 수평면에 서의 각도가 비역을 기준으로 $54.5 \pm 6.8^{\circ}$ 를 이루고 있었다. 비공
아랫점으로부터 전사골동맥관까지의 거리는 $53.6 \pm 4.9 \mathrm{~mm}$ 였 으며 경구개에 평행하는 수평면과 이루는 각도는 비공 아랫점 을 기준으로 $51.4 \pm 6.4^{\circ}$ 를 이루고 있었다.

본 연구에서는 Eloy 등이이 제시하였던 지표들을 사용하여 한국인 성인남녀를 대상으로 시상면 영상을 통한 전두동 자연 공의 방사선학적 계측을 하였다. 비주로부터 비전두동 부리까 지의 평균거리는 본 연구의 한국인 성인남자에서는 $55.3 \pm 3.9$ $\mathrm{mm}$, 한국인 성인여자에서는 $52.1 \pm 4.7 \mathrm{~mm}$ 였다. 비주로부터 전뇌기저부까지의 평균거리는 한국인 성인남자에서는 $62.1 \pm$ $4.5 \mathrm{~mm}$, 한국인 성인여자에서는 $59.0 \pm 4.7 \mathrm{~mm}$ 였다. 비주에 서 비전두동 부리를 지나 전뇌기저부까지의 직선과 경구개에 평행하는 수평면과의 평균각도는 한국인 성인남자에서는 71.8 $\pm 4.5^{\circ}$, 한국인 성인여자에서는 $70.7 \pm 4.6^{\circ}$ 였다.

본 연구는 한국인 성인에서 전두동 자연공을 중심으로 비 강 입구까지의 거리를 측정하는 데에 의의가 있다고 생각한다. 그러나 제한점으로는 사체 연구를 통한 해부학적 계측이 아 닌 방사선학적인 계측으로 본 연구결과를 실제 부비동 내시 경 수술에 완전히 그대로 적용하기에는 한계가 있을 수 있다. 본 연구결과를 통해 전두동 내시경 수술시 한국인 성인남 자는 비주에서 $57.6 \mathrm{~mm}$, 성인여자는 $54.3 \mathrm{~mm}$ 의 직선 거리 이하를 유지해야 부주의한 전뇌기저부 손상을 최소화할 수 있을 것으로 생각된다.

\section{REFERENCES}

1) Jung JH, Jin BJ, Jeong JH, Cho SH, Lee SH, Kim KR. Effects of frontal recess cells on the development of frontal sinusitis. Korean J Otorhinolaryngol-Head Neck Surg 2012;55(11):693-700.

2) Moon IH, Sung JY, Park HM, Park JY, Chang CS, Jeong KW. Comparative analysis on anatomical measurements of paranasal sinuses using nasal endoscope and CT. Korean J Otolaryngol-Head Neck Surg 1998;41(6):736-9.

3) Oh SC, Cha HE, Jang IH, Kim ST, Park BH, Kim CW, et al. The evaluation and measurement of anterior ethmoidal canal in axial OMU CT. Korean J Otolaryngol-Head Neck Surg 1999;42(5):599602.

4) Moon HJ, Kim HU, Lee JG, Lee KH, Chung IH, Yoon JH. Surgical anatomy of the anterior ethmoidal canal in ethmoid roof: anatomical and computed tomographic analysis. Korean J Otolaryngol-Head Neck Surg 2001;44(8):822-6.

5) Shin JM, Jang WI, Baek BJ. Analysis of sphenoid sinus and surrounding structures using multidetector computed tomography. Korean J Otorhinolaryngol-Head Neck Surg 2012;55(2):95-100.

6) Burkart CM, Zimmer LA. Endoscopic modified Lothrop procedure: a radiographic anatomic study. Laryngoscope 2011;121(2):442-5.

7) Kim K, Lim SC. Image-guided surgery in the paranasal sinus and skull base lesion. Korean J Otolaryngol-Head Neck Surg 2006;49(11): 1082-6.

8) Eloy JA, Neskey DM, Vivero RJ, Ruiz JW, Choudhry OJ, Casiano RR. High-resolution computed tomography analysis of the frontal sinus ostium: a pilot study. Am J Otolaryngol 2013;34(2):99-102. 